\title{
Effect of specific humoral immunity and some non-specific factors on resistance of volunteers to respiratory coronavirus infection
}

\author{
BY KATHLEEN A. CALLOW \\ Common Cold Research Unit, Harvard Hospital, \\ Coombe Road, Salisbury, Wiltshire, U.K.
}

(Received 28 November 1984; accepted 18 February 1985)

\begin{abstract}
SUMMIARY
Thirty-three volunteers were inoculated intranasally with coronavirus $229 \mathrm{E}$, and their responses monitored by antibody rises, symptomatology and virus excretion. These were related to their pre-trial immune status as indicated by concentrations of specific antibodies and non-specific proteins in serum and nasal washings. Both circulating and local specific antibodies were associated with protection from infection and disease, but only specific IgA antibodies of either type appeared to shorten the period of virus shedding: Although total secretory IgA was significantly associated only with reduction of symptoms, total protein in nasal washings appeared to protect against infection also, indicating that other locally produced proteins, not identified, may be associated with resistance.

Two of the many factors which may affect the concentration of circulating and local protective proteins and thus influence the outcome of virus inoculation, namely, sex of the volunteer and the interval since the previous cold, were examined. Male volunteers or volunteers who had had evidence of a recent respiratory infection were less likely to be infected, but if they were infected, they had lower clinical scores and stopped shedding virus earlier than the rest. These groups possessed higher concentrations of specific antibodies and non-specific proteins in their pre-challenge sera and/or nasal washings. The significance of these findings is discussed.
\end{abstract}

\section{INTRODUCTION}

Infection with many respiratory viruses confers resistance to reinfection but the amount and mechanism seem to vary and remain obscure. In experimental parainfluenza or respiratory syncytial virus infection of adults, resistance appeared to be primarily associated with the presence of local nasal secretory antibody (Smith et al. 1966; Mills et al. 1971). In contrast, circulating antibody seems to confer protection against adenovirus infections (Edmondson et al. 1966). The results of experimental influenza infections have been confusing. Local antibody was shown to be important in some studies (Clements et al. 1983) especially in volunteers selected to have low circulating antibody titres (Murphy et al. 1973). Another study of volunteers with a wider range of serum titres showed serum antibody to be more important than secretory antibody (Freestone et al. 1972). Experimental rhinovirus infections showed that circulating antibody titres do not 
always predict resistance very precisely and that secretory antibodies are certainly protective (Perkins et al. 1969; Reed \& Hall, 1973).

There is also evidence of a correlation between non-specific local immunity and protection, in that total nasal protein or immunoglobulins, especially IgA, are associated with resistance to respiratory virus infections (South et al. 1968; Rossen et al. 1970). While the precise relationship is unknown, total nasal secretory immunoglobulins are elevated for some weeks after respiratory infections (Butler et al. 1970) and resistance to colds is increased for a similar period after natural infections (Lidwell \& Williams, $1961 b$; Holmes et al. 1976).

Coronaviruses cause about $20 \%$ of all colds (Monto, 1974), but the relative importance of these different immune mechanisms in coronavirus infections has not been investigated. Though some subjects are resistant, experimental infections can be readily produced. Enzyme-linked immunosorbent assays (ELISA) have been developed to measure coronavirus antibodies (Kraaijeveld, Madge \& Macnaughton, 1980). They are sensitive and specific and have been adapted in this study to measure antibody class. The contribution of specific antibodies, and nonspecific proteins, both local and circulating, to resistance to coronavirus infection was measured in volunteers. Also the effects of two factors which appear to influence the concentration of these, namely recent clinical respiratory infection and the sex of the volunteer, were analysed.

\section{MATERIALS AND METHODS}

\section{Volunteers}

Isolation, inoculation, monitoring and assessment procedures have been described elsewhere (Beare \& Reed, 1977; Higgins et al. 1983). Thirty-three volunteers, 12 males and 21 females, were inoculated intranasally with 89-407 TCID ${ }_{50}$ of the LP strain of coronavirus $229 \mathrm{E}$, contained in a filtered nasal wash. Because they were the placebo group of a prophylactic drug trial they were treated with a selfadministered intranasal spray (three times daily for 4 days) containing buffer and human albumen. The trial was approved by the Northwick Park Hospital ethical committee.

\section{Specimens}

Blood samples were collected prior to virus challenge and, to detect antibody rises, again 2-3 weeks after challenge; after separation the sera were stored at $-20^{\circ} \mathrm{C}$ and heated at $56^{\circ} \mathrm{C}$ for 30 min before use.

Total nasal secretion weight was obtained by weighing all the tissues used after virus inoculation and subtracting the mean weight of unused tissues.

Nasal washings were collected two days before virus challenge and, to detect virus shedding, on days 2-6 afterwards. Five millilitres of Hanks' buffered saline were instilled into each nostril, collected and stored in two separate aliquots. Titrations for virus excretion were performed in the C-16 line derived from MIRC-C cells (Phillpotts, 1983) on washings stored at $-70^{\circ} \mathrm{C}$. Pre-challenge nasal washings for assay of total and specific immunoglobulins, and total protein were shaken with glass beads, centrifuged to sediment the mucus and stored at $-20^{\circ} \mathrm{C}$. The latter were tested for the presence of blood by the Haemastix test (Niles Laboratories Ltd) and excluded if they gave more than a trace reaction. 
Specific and total immunoglobulins in sera

Neutralizing antibody to LP virus was measured by a micro-neutralization test (Higgins et al. 1983) in C-16 cells.

\section{ELISA test for specific antibodies in sera}

This was an adaptation of that described elsewhere (Kraaijeveld, Madge \& Macnaughton, 1980; Callow, 1983). Optimum dilutions of each reagent were chosen from ehequerboard titrations.

Coronavirus $229 \mathrm{E}$, used as antigen, was grown in C-16 cells. Infected tissue cultures were disrupted by freezing and thawing, clarified by low-speed centrifugation, and stored at $-70^{\circ} \mathrm{C}$.

Inactivated sera were diluted in phosphate-buffered saline containing $0.05 \%$ Tween 20 ('TPBS) and $5 \%$ of an extract of uninfected C-16 cells (control antigen).

Anti-human $\operatorname{IgG}$ produced in swine, conjugated to alkaline phosphatase (Northumbria Biologicals) was used at 1 in 400 . Goat anti-human IgA ( $\alpha$ chain) and goat anti-human IgII ( $\mu$ chain) conjugates (Sigma Chemical Co.) were both used at 1 in 1000. The anti-human IgA conjugate showed a low cross reaction (data not shown) with purified human IgG (Sigma Chemical Co.), which was blocked by adding $2.5 \mu \mathrm{g} / \mathrm{ml}$ of human IgG, which had insignificant coronavirus-specific IgG. The IgG and IgMI conjugates showed no significant cross-reaction with each other, or with IgA.

The substrate, $p$-nitrophenol phosphate (Sigma) was dissolved in $10 \%$ diethanolamine buffer at $1 \mathrm{mg} / \mathrm{ml}$.

Nunc polystyrene micro-ELISA plates (Gibco, Ltd) were coated with virus or control antigen at about $8 \mu \mathrm{g}$ protein $/ \mathrm{ml}$ in carbonate/bicarbonate buffer $\mathrm{pH} \mathbf{9 \cdot 6}$ and incubated overnight at room temperature (RT). Next day, and between all further steps, the plates were washed three times with TPBS. Diluted specimens were added and the plates left at RT for $4 \mathrm{~h}$, after which conjugates, diluted in TPBS, were added and the plates left at RT overnight. Next day substrate was added and the plates left at RT for $30 \mathrm{~min}$ or longer for the colour to develop. Optical density (OD) was read with a Titertek Multiskan ELISA reader (Flow Laboratories) at $405 \mathrm{~nm}$. The low ODs obtained in wells without samples were subtracted from the ODs in wells with samples and then the adjusted ODs obtained in control antigen-coated wells were subtracted from those obtained in virus-coated wells.

\section{Measurement of IgG ELISA ratios (antibody rises) in sera}

Rises of specific serum IgG were detected by obtaining the post/pre-challenge ELISA OD ratios at serum dilutions of 1 in 50, 1 in 100 and 1 in 200 and recording the highest ratio (ELISA ratio). ELISA ratios from ODs read at $2 \mathrm{~h}$ were used, as the ratio reached a maximum at this time.

The mean ELISA ratio of 14 volunteers given a saline inoculum was 1.04 and the standard deviation (s.D.) 0.158. The mean ratio plus three S.D.s was 1.51 and a ratio of $>1.5$ was taken to be indicative of a significant antibody rise. Selected paired sera which showed rises of $229 \mathrm{E}$-specific IgG were also reacted with antigen prepared from the related OC 43-type coronavirus, Paris strain, and no rise was observed. 
Total immunoglobulins in sera (i.e. IgG, IgA and IgM) were mensured by laser nephelometry with a disk 120 sampling system and Las-R reference sera (Hyland Laboratories).

\section{Specific and total proteins in nasal washings}

Total protein in nasal washings was measured by the method of Lowry et al. (1951).

\section{Measurement of total IgA and IgG in nasal washings by ELISA}

Conjugates, substrate, washing methods and $O D$ measurement were as described above. ELISA plates were coated overnight with a rabbit anti-human $\alpha$ chain IgA serum (Hocchst UK Ltd) or gont anti-human IgG (Sigma) at about $5 / \mathrm{cg} / \mathrm{ml}$ protein in coating buffer. Nasal washings diluted 1 in 4000 for IgA assay or 1 in 500 (IgG) were added and the plates incubated $6 \mathrm{~h}$ at $4{ }^{\circ} \mathrm{C}$. A standard curve of doubling dilutions of human IgG or colostrum IgA (Sigma) diluted in TPBS was set up on each plate. Bound IgA and IgG were detected as described above.

\section{Measurement of specific IgA in nasal washings}

Samples were diluted 1 in 20 in $5 \%$ control antigen in TPBS and added to wells coated with virus or control antigen in the same experiment in which total IgA was assayed. The low ODs obtained against control antigen were subtracted from those obtained in virus-coated wells, and the concentrations rend off from the IgA standard curve.

\section{Statistical analysis}

In order to analyse the effect of immune status on infection and clinical response, volunteers were divided into pairs of groups on the basis of ELISA ratios $(<$ or $\geqslant 1 \cdot 5)$, clinical scores $(<$ or $\geqslant 5)$, total nasal secretion weight $(<$ or $\geqslant 5 \mathrm{~g}$ ). Groups were also selected on the basis of duration of virus shedding ( $<$ or $\geqslant 5$ days) and time since a previous cold ( $\leqslant$ or $>6$ months). These groupings all divided the volunteers into roughly equal numbers, but the groups did not necessarily contain the same individuals with each division.

The differences between the groups, e.g. antibody or immunoglobulin concentration, were analysed by a one-tailed analysis of variance based on ranks, because some of the data could not be normalized. Similarly, rank correlation was used to correlate one continuous variable with another using the whole group. Probabilities were obtained from Spearman's coefficient of rank correlation, using table 87 in Siegel (1956). The statistical analysis was carried out on a Sirius 1 microcomputer using the program Statistical Package for Personal Computers (SPP, Patrick Royston, Clinical Research Centre, Northwick Park Hospital, Harrow). The rank analysis of variance used a facility whereby a third variable was allowed for, by 'blocking' data into groups according to the values of the third variable, e.g. serum antibody.

\section{RESULTS}

\section{Agreement between the measures of infection}

Infection or disease was defined by ELISA ratios (serum IgG antibody rises), clinical scores, total nasal secretion weight and duration of virus shedding. Clinical score showed the highest rank correlation with the other parameters ('Iable 1), 
'Table 1. Rank correlation coefficients* of measures of infection

\begin{tabular}{|c|c|c|c|}
\hline & ELISA ratio & $\begin{array}{c}\text { Duration of } \\
\text { virus shedding }\end{array}$ & $\begin{array}{l}\text { Total nasal } \\
\text { secretion weight }\end{array}$ \\
\hline Clinical score & 0.76 & 0.59 & $0 \cdot 91$ \\
\hline $\begin{array}{l}\text { ELISA ratio } \\
\text { (antibody rise) }\end{array}$ & - & 0.61 & $0 \cdot 66$ \\
\hline $\begin{array}{l}\text { Duration of } \\
\text { virus shedding }\end{array}$ & 一 & - & $0 \cdot \overline{5} 3$ \\
\hline
\end{tabular}

* All coefficients were significant at $P<0.001$.

especially with total nasal secretion weight. The results which follow show that nasal secretion weight showed a similar response pattern to clinical score. Data of secretion weights have been included in the tables, because they represent a purely objective indication of disease.

Of the nine individuals who showed no antibody rise or clinical sign of infection, five shed virus, and this may explain why shedding showed least agreement with the other parameters of infection. This demonstrated that while agreement between the different measures was always highly significant a different treatment of the virus shedding data was justified (see below).

\section{Correlation between pre-challenge concentrations of serum and secretory proteins}

These factors generally showed positive correlations with each other (Table 2), for example serum neutralizing antibody with serum specific IgG or nasal washing specific IgA concentrations, both as measured by ELISA. Similarly, amounts of the different classes of total immunoglobulins in sera correlated; and though not always statistically significant, specific antibody often correlated with total immunoglobulins of that class, in serum or in nasal washings.

However, serum specific and total IgA concentrations were inversely correlated to neutralizing antibody titres $(P<0.05$ and $<0.01$ respectively) and to a lesser extent to specific IgG. There was also a trend towards an inverse relationship between total IgM and neutralizing antibody. A negative correlation of specific IgA with specific IgG could arise because large amounts of specific IgG might compete with IgA for binding sites in the ELISA test, but this cannot account for all the negative correlations. Because of this inverse relationship it was important to allow for (block with) such a variable (e.g. serum total IgA) when examining the effect of, for example, neutralizing antibody on infection and disease. Another unexpected finding was a lack of correlation between specific IgA concentration in nasal washings and serum, and similarly between total IgA concentrations in these fluids.

\section{Relationship between specific antibodies and infection or disease}

Uninfected or asymptomatic volunteers had much more neutralizing antibody in their pre-challenge serum than affected volunteers $(P<0.001)$ ('Table 3). The difference between the groups was over six-fold where infection was defined by significant ELISA ratios, i.c. antibody rises. The measures of infection, except for virus shedding, correlnted negatively with neutralizing antibody titres $(P<0.01$ or $<0.05$ ). Serum specific IgG as measured by ELISA showed a similar pattern, although the differences were smaller and less significant. (Optical densities of $0 \cdot 14$ 


\section{Kathleen A. Callow}
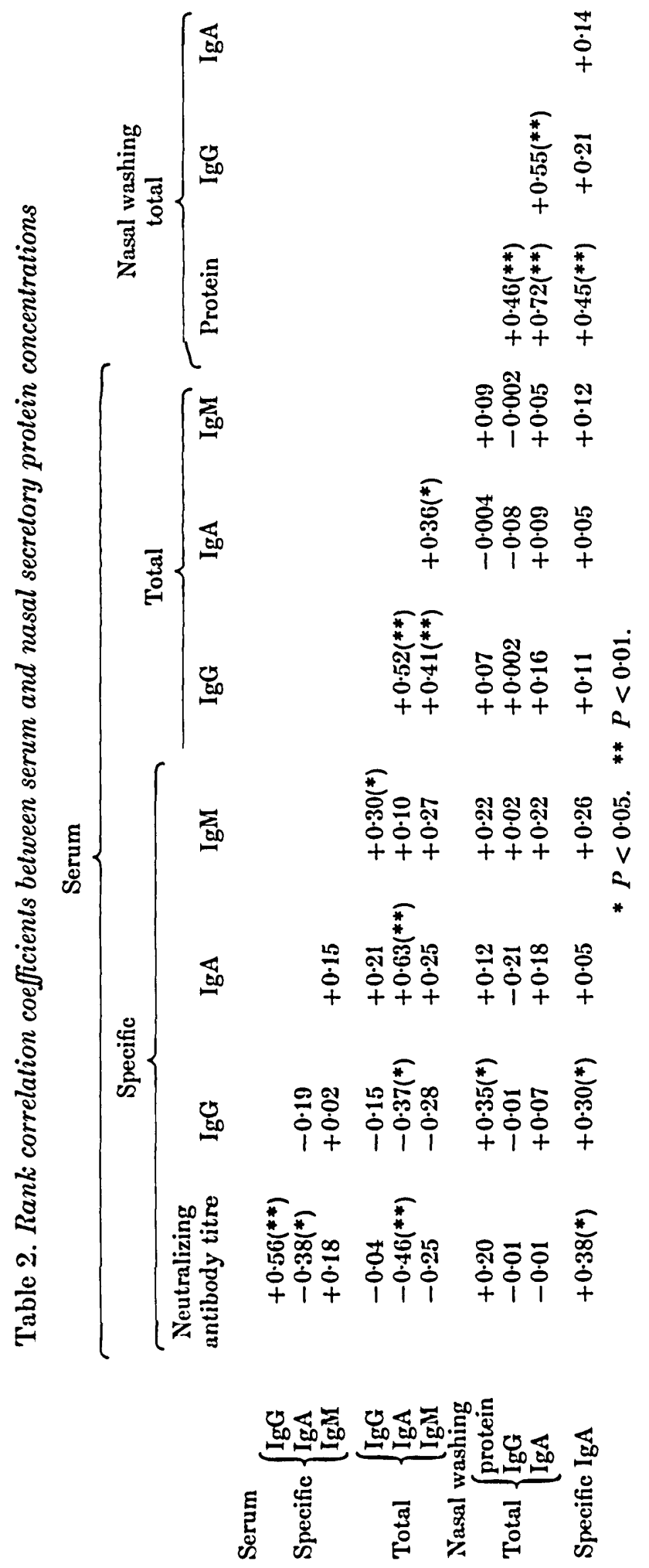


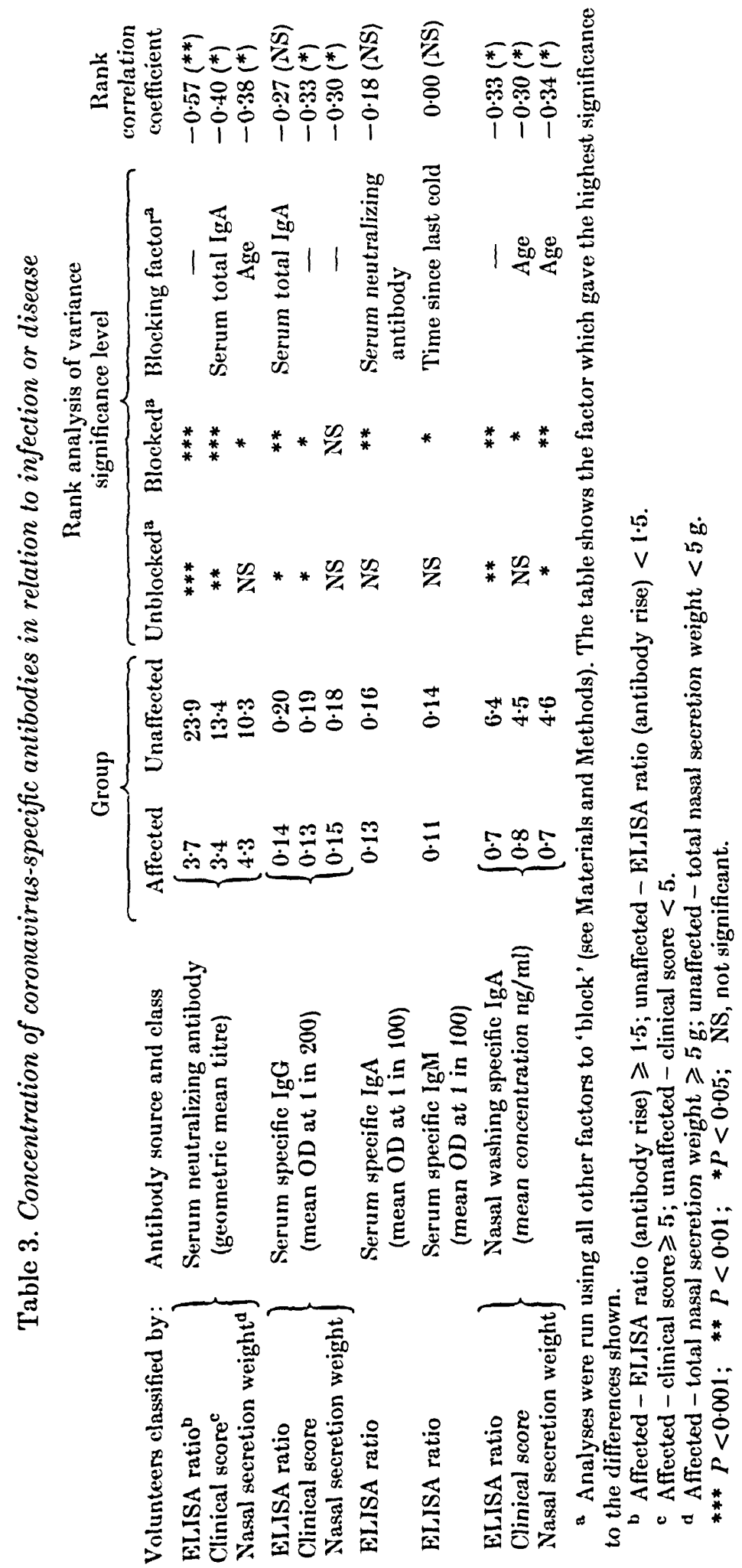


Kathleen A. Callow

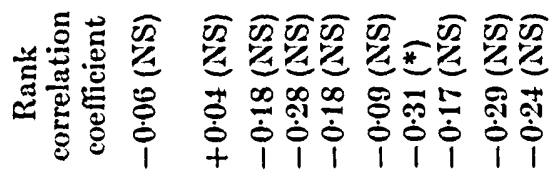

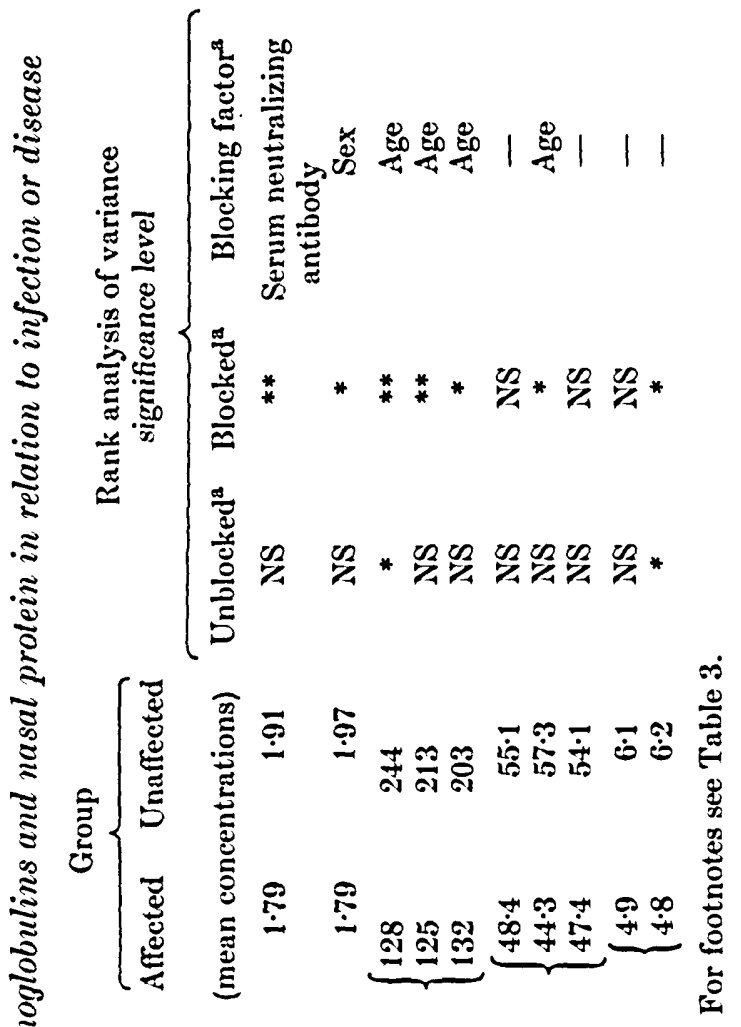

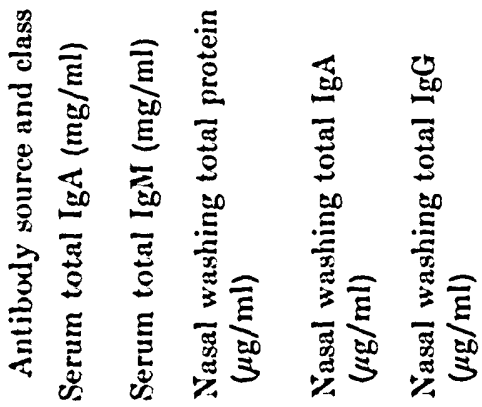

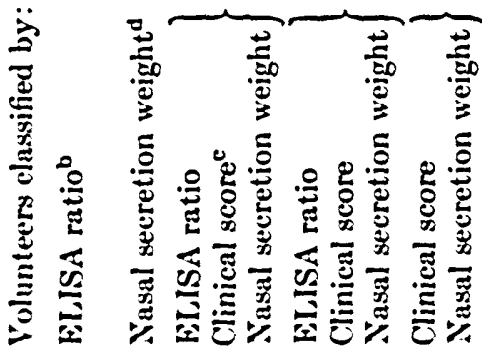


and 0.20 correspond to reciprocal specific IgG titres of 900 and 1350 .) Concentrations of serum specific IgA were also lower in the infected group as defined by ELISA ratios $(P<0.01$ when allowing for neutralizing antibody titres). The mean ELISA OD due to specific IgM was also lower in this group $(P<0.05)$, but the relationship was not confirmed by rank correlation. Concentrations of serum IgA and IgMI antibodies were similar in symptomatic and asymptomatic volunteer groups (data not shown).

There were also large differences in pre-challenge secretory specific IgA concentrations between affected and unaffected volunteers in all three groups $(P<0.01$ or $<0.05$ ). The mean concentration in uninfected (ELISA ratio $<1.5$ ) volunteers' pre-trial secretions was $>9$-fold higher than in the infected group (ELISA ratio $\geqslant 1 \cdot 5$ ). These differences were confirmed by significant negative rank correlations.

\section{Relationship between non-specific factors and infection or disease}

There was no difference in serum total IgG concentration between any of the groups (data not shown). Serum total IgA was slightly higher in the uninfected ELISA ratio group than in the infected group $(P<0.01$ allowing for neutralizing antibody titre) and serum total IgM was slightly higher in the group with a low nasal secretion weight compared with the rest $(P<0.05$ allowing for sex of the volunteer) (Table 4). Neither of these findings was supported by rank correlation, or by classifying volunteers by clinical score, etc.

On the other hand, the concentration of total protein in the nasal washings of the affected volunteers was much lower than in those unaffected; while not supported by significant rank correlation, the differences were significant in the rank analysis of variance by allowing for age of the volunteer.

Also, nasal total IgA concentration was somewhat lower in affected volunteers, but this difference was significant only in the case of clinical score $(P<0.05)$ by both statistical methods. There also appeared to be significantly less of this immunoglobulin $(P<0.05$, allowing for age) in nasal washings of those with colds compared with those without, a separate parameter of clinical assessment (data not shown).

Total IgG in nasal washings from symptomatic volunteers was lower than in those from asymptomatic volunteers, though the difference was only significant $(P<0 \cdot 05)$ where groups were defined by nasal secretion weight.

\section{Immune status and virus shedding}

Since only 4 of the 33 volunteers were not infected judging by virus shedding, the group was split according to the duration of virus shedding; those who were still shedding virus at the end of the trial, i.e. shedding for at least 5 days, and those who had shed virus for less than 5 days (Table 5).

Serum neutralizing antibody and serum specific IgG concentrations were only slightly lower in the group $(P>0.05$, not significant) which shed virus for 5 days or more. However, the concentrations of secretory and serum specific IgA, serum total IgA and secretory total protein were considerably lower in this group $(P<0.01$ or $<0.05)$. Furthermore, these concentrations correlated negatively with durntion of virus shedding. The negative correlation coefficient of secretory specific $\operatorname{Ig} A$ with duration of virus shedding $(r=-0.45, P<0.01)$ was only 


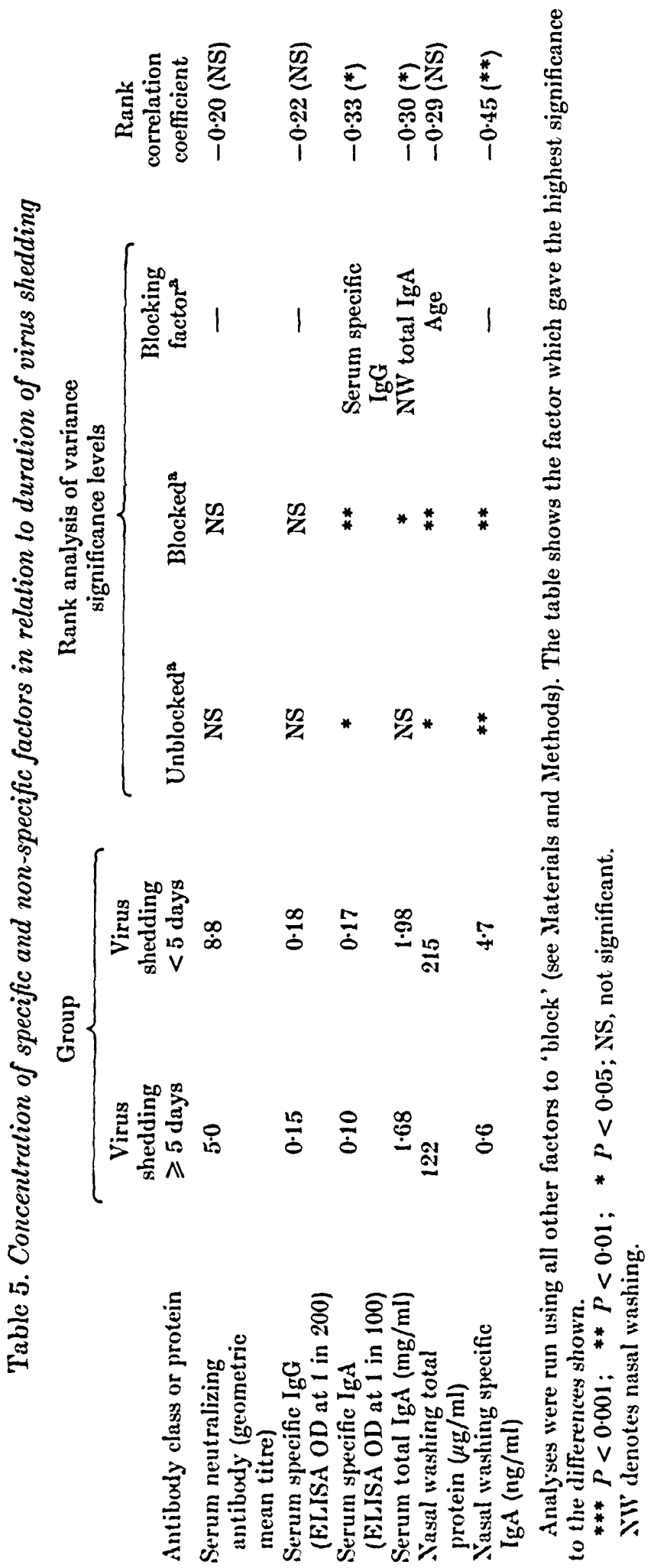




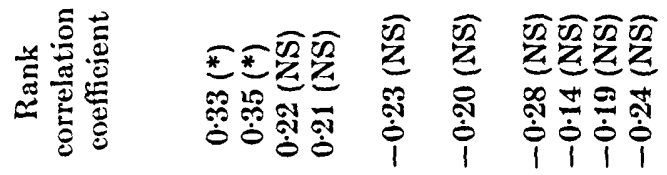

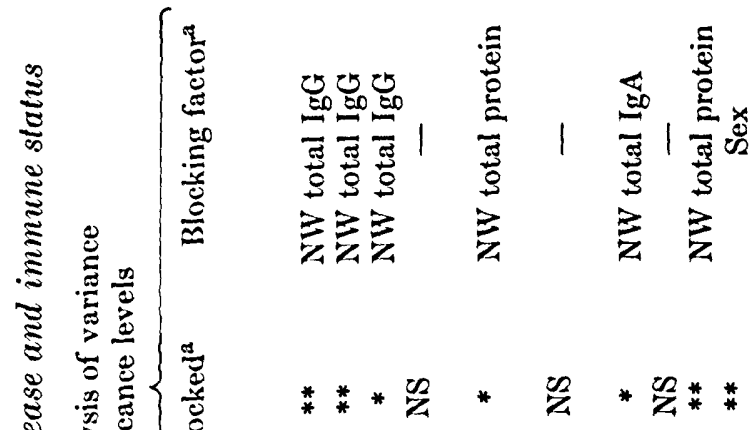

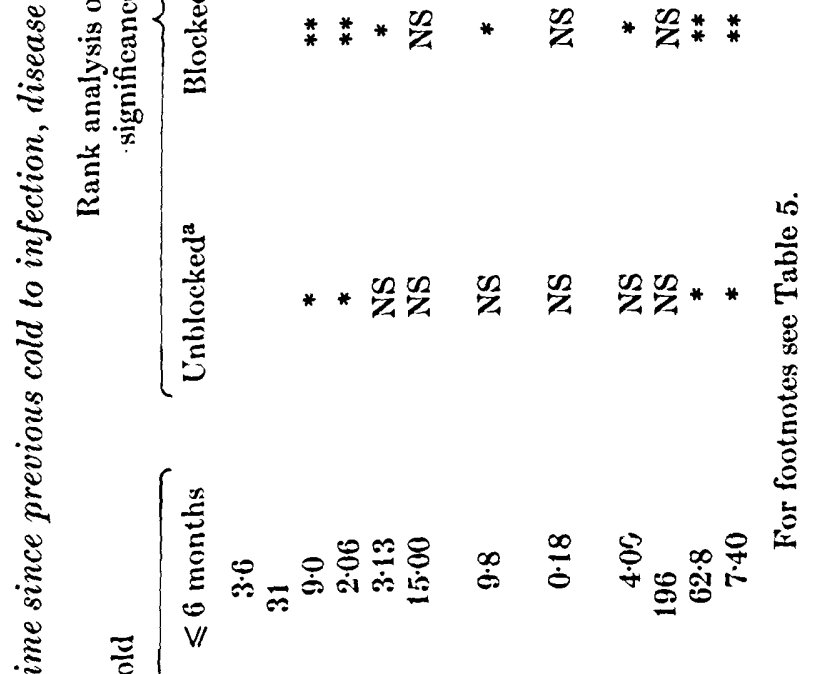

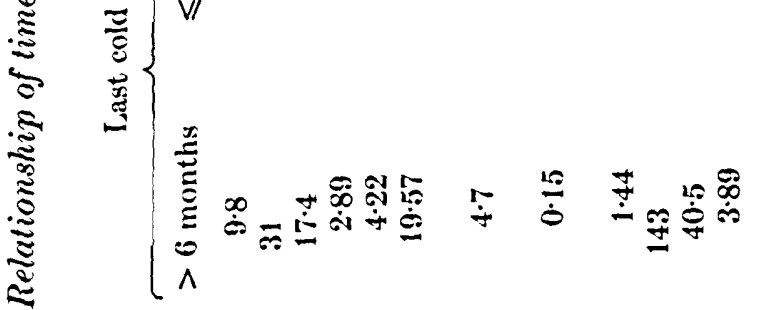

$\dot{0}$

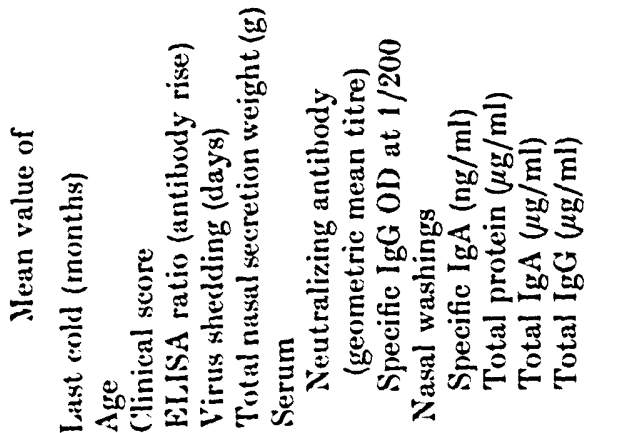


Table 7. Relationship of sex to infection, disease and immune status

\begin{tabular}{|c|c|c|c|c|c|}
\hline \multirow[b]{2}{*}{ Mean value of: } & \multicolumn{2}{|c|}{ Sex } & \multicolumn{3}{|c|}{$\begin{array}{l}\text { Rank analysis of variance } \\
\text { significance levels }\end{array}$} \\
\hline & Female & Male & Unblocked $^{\mathrm{a}}$ & Blocked $^{\mathrm{a}}$ & Blocking fnctor ${ }^{\mathrm{a}}$ \\
\hline Age & 32 & 28 & NS & NS & - \\
\hline Last cold & 7.05 & 6.83 & NS & NS & - \\
\hline Clinical score & $19 \cdot 05$ & $3 \cdot 96$ & ** & *** & Last cold \\
\hline ELISA ratio & $2 \cdot 78$ & 1.97 & $*$ & $*$ & - \\
\hline Virus shedding (dnys) & $\mathbf{3 \cdot 9 5}$ & $3 \cdot 33$ & NS & $*$ & Serum total IgA \\
\hline $\begin{array}{l}\text { Total nasal secretion } \\
\text { weight }(\mathrm{g})\end{array}$ & $25 \cdot 44$ & $3 \cdot 57$ & $* *$ & $* * *$ & Serum total Ig II \\
\hline Serum & & & . & & \\
\hline $\begin{array}{l}\text { Neutralizing antibody } \\
\text { (geometric mean titre) }\end{array}$ & $5 \cdot 06$ & $10 \cdot 52$ & NS & NS & - \\
\hline Specific IgG OD $1 / 200$ & $0 \cdot 14$ & 0.21 & ** & ** & - \\
\hline Total IgA (mg/ml) & 1.90 & 1.69 & NS & NS & - \\
\hline Total IgMI (mg/ml) & $2 \cdot 03$ & 1.61 & $*$ & $* *$ & Last cold \\
\hline Nasal washing & & & & & \\
\hline Specific IgA (ng/ml) & 1.71 & $4 \cdot 17$ & NS & * & Age \\
\hline Total protein $(\mu \mathrm{g} / \mathrm{ml})$ & 122 & 246 & * & * & - \\
\hline Total IgA $(\mu \mathrm{g} / \mathrm{ml})$ & $44 \cdot 8$ & $60 \cdot 9$ & NS & * & $\begin{array}{l}\text { Neutralizing } \\
\text { antibody }\end{array}$ \\
\hline Total IgG $(\mu \mathrm{g} / \mathrm{ml})$ & 4.09 & 8.00 & ** & $* *$ & - \\
\hline
\end{tabular}

surpassed by that of neutralizing antibody with ELISA ratios ('Table 3). Total immunoglobulins other than serum IgA did not appear to relate to virus shedding (data not shown).

Recent respiratory disease, immune slatus and infection or disease

Those volunteers whose previous cold was less than 6 months before the trial appeared to be more resistant to infection (as judged by ELISA ratios), shed virus for a shorter time, had lower clinical scores and produced less secretion than the rest ('Table 6). The differences were particularly significant statistically in the case of ELISA ratios and clinical scores. These volunteers also had considerably higher concentrations of most of the specific and non-specific factors examined in serum and secretions. Although not supported by rank correlation, the difference usually became statistically significant in the rank analysis of variance when other factors were blocked.

\section{Sex, immune status and infection or disease}

Female volunteers had much higher clinical scores and nasal secretion weight $(P<0.001)$ and rather higher ELISA rasios $(P<0.05)$ than males ('Table 7$)$. They also had less serum neutralizing antibody and specific IgG and a significently lower concentration of all the secretory proteins. However, the women had more serum total IgA and IgNI ( $P<0.01$ in the case of IgN). 


\section{DISCUSSION}

The data obtained in this study show that presence of high concentrations of neutralizing antibody (or specific IgG) in serum, and specific IgA in secretions, before challenge, were both important factors in the prevention of infection with coronavirus $229 \mathrm{E}$, as measured by antibody rises. Furthermore, if volunteers became infected, these antibodies were clearly associated with reduction of symptoms, including the amount of nasal secretion. Other studies have demonstrated that resistance to disease and infection from respiratory viruses is mediated by circulating antibodies (Edmondson et al. 1966; Hendley, Gwaltney \& Jordan, 1969; Couch et al. 1984) and similar results were obtained by Hamre $\&$ Beem (1972) and Reed (1984) with coronavirus. In contrast, other workers have noted the protective effect of secretory antibodies (Smith et al. 1966; Mills et al. 1971 ; Perkins et al. 1969; Clements et al. 1983). However, the studies of Tremonti, Lin \& Jackson (1968) suggested that in parainfluenza infections both types of antibody were important for full immunity, as was evident in this study.

Nevertheless, although the effects of both types of antibody on clinical scores and infection, as measured by antibody rises, were similar, it appeared that local specific IgA was more effective than circulating specific IgG or neutralizing antibody at terminating virus shedding. Possibly local IgA antibody may have neutralized small amounts of virus present in the secretions so that it could not be detected. However, although serum specific IgA appeared relatively ineffective at preventing symptoms and antibody rises, it also was much more effective than serum specific IgG or neutralizing antibody at stopping virus shedding. Buscho et al. (1972) and Couch et al. (1984) also noted the particular effect of secretory specific IgA on rhinovirus shedding, while Cate et al. (1966) showed that serum neutralizing antibody did not shorten rhinovirus infections.

High concentrations of total nasal protein appeared to protect volunteers from infection and disease and to shorten the period of virus shedding; this has also been noted in other volunteer trials (Callow, unpublished observations). The main protective factor in nasal secretion protein may be total IgA (South et al. 1968; Rossen et al. 1970; MICCormick et al. 1972). Although there was no clear evidence in this study that total secretory IgA protected against infection it did appear to reduce clinical scores significantly. Cate et al. (1966) suggested that non-specific protection assumed importance once rhinovirus infection had begun. Some of the protein may represent immunocompetent cell debris or particles of mucus not removed in clarification (Rossen et al. 1966) and these may bind specific antibodies or immunoglobulins (Heremans, 1975). Furthermore, secretions contain other weakly antiviral substances, probably glycoproteins (Matthews et al. 1976).

Recent respiratory disease was clearly associated with protection, supporting early epidemiological studies (Lidwell \& Williams, 1961b). This could be explained by the fact that these recently affected volunteers had more circulating and secretory specific antibodies than those with earlier infections. Antibody to $229 \mathrm{E}$ may have arisen from infection with this coronavirus strain, but it may also have been stimulated by other heterologous strains, as has been observed in rhinovirus (Fleet et al. 1965) and influenza infections (reviewed by Couch et al. 1984).

Coronavirus-specific antibody could have been stimulated by infection with 
unrelated viruses, which apparently stimulates heterologous antiviral antibodies (Holmes, 1973). Tyrrell \& Reed (1973) showed that infection with rhinoviruses appears to provide short-term protection from influenza infection. Butler et al. (1970) and MIcCormick et al. (1972) showed an increase in total secretory immunoglobulins after respiratory infections, and this may include specific antibody to previously encountered antigens by an anamnestic response.

In this study volunteers who had had colds less than 7 months before the trial were excreting more total IgA and IgG than those with earlier infections. Crifo et al. (1980) found similar increases after infection, but these began to decline by 30 days. However, as noted above, other non-specific proteins may be stimulated by infection which could be more long lasting.

Immunity after infection might also be partly due to regenerating nasal epithelium (Cate et al. 1964), which was shown to be resistant to influenza infection in ferrets (Stuart-Harris \& Francis, 1938), or stimulation of local cell-mediated immune mechanisms (Waldman \& Henney, 1971).

There appeared to be a variety of interactions between the various protective factors in that their concentrations might correlate positively, negatively or not at all. Thus the fact that several different factors had similar effects on infection and disease was not always, or only, due to their being alternative measures of one protective mechanism such as immunoglobulin concentration. For example, serum neutralizing antibody or specific IgG correlated with local specific IgA, agreeing with Artenstein, Bellanti \& Buescher (1964), who showed a correlation between local and systemic neutralizing antibody titres to several respiratory viruses. However, as indicated by Tomasi \& Decoteau (1970) and Yodfat \& Silvian (1977), there was no correlation between total IgA concentrations in the circulation and secretions, implying that they are under different control mechanisms. Furthermore, there was an inverse relationship between the concentrations of serum neutralizing antibody or specific IgG and serum total or specific IgA. Other studies have shown that immunodeficiency of IgA can be compensated for by secretory IgG and/or IgM, both specific (Ogra et al. 1974; Arnold et al. 1978) and total ('Tomasi et al. 1965; Savilahti, 1073).

The inverse relationship could be partly due to the fact that female volunteers had more serum total IgA but less neutralizing antibody or specific IgG than the males. Rhodes et al. (1969) showed rather similar differences in the proportions of immunoglobulins between the sexes. The relative lack of these last two types of antibody, and of secretory proteins, may indicate why women succumbed more to infection than men, as also shown by epidemiological studies (Lidwell \& Sommerville, 1951; Lidwell \& Williams, 1961 a). The differences have been attributed to exposure to children with their higher incidence of infection. However, this did not apply in this study, and we have found other evidence for women volunteers being more susceptible to infection with respiratory viruses (Callow, unpublished observations). If sex influences the proportions and concentrations of immunoglobulins it may be that their synthesis is under hormonal control, or it could bo that women are more subject to the types of 'stress' which influence immunoglobulin concentrations (Jemmott et al. 1983) or rates of infection (Totman, Reed \& Craig, 1977; Totman et al. 1980).

In conclusion, resistance to infection and disense from coronavirus appenrs to 
be due to several interrelating factors, and in future studies we shall investigate the effects of other factors, such as age, atopy, sensitivity of the mucous membranes and cell-mediated immune responses.

I thank Dr D. A. J. Tyrrell and others for helpful discussion during the course of this work, and Mrs N. Bailey for expert technical assistance. I am grateful also to Mrs J. Acornley for help with the computer analyses and to Mrs J. Tuer, of the Clinical Research Centre, Northwick Park Hospital, Harrow, for assaying total immunoglobulins in sera.

\section{REFERENCES}

Arnold, R. R., Prince, S. J., Mestecky, J., Lynch, D., Lynch, M. \& McGhee, J. R. (1978). Secretory immunity and immunodeficiency. Advances in Experimental Biology and Medicine 107, 401-410.

Artenstein, M. S., Bellanti, J. A. \& Bunscher, E. L. (1964). Identification of the antiviral substances in nasal secretions. Proceedings of the Society for Experimental Biology and Medicine 117, 558-564.

Beare, A.S. \& REed, S. E. (1977). The study of antiviral compounds in volunteers. In Chemoprophylaxis and Virus Infections of the Respiratory Tract, vol. II (ed. J. S. Oxford), pp. 27-55, Cleveland: CRC Press.

Buscho, R. F., Perkins, J. C., Knopf, H. L. S., Kapikian, A. Z. \& Chanock, R. M. (1972). Further characterization of the local respiratory tract antibody response induced by intranasal instillation of inactivated rhinovirus 13 vaccine. Journal of Immunology 108, 169-177.

Butler, W. T., Waldnan, T. A., Rossen, R. D., Gordon Douglas, R., JR \& Couch, R. B. (1970). Changes in IgA and IgG concentrations in nasal secretions prior to the appearance of antibody during viral respiratory infection in man. Journal of Immunology 108, 584-591.

Callow, K. A. (1983). Measurement of antibodies to influenza virus neuraminidase by an enzyme-linked immunosorbent assay. Infection and Immunity 41, 650-656.

CATE. T. R., Couch, R. B. \& Johnson, K. MI. (1964). Studies with rhinovirus in volunteers: production of illness, effect of naturally acquired antibody, and demonstration of a protective effect not associated with serum antibody. Journal of Clinical Investigation 43, 56-67.

Cate, T. R., Rossen, R. D., Gordon-Dovglas, R., Jr, Butler, IV. T. \& Couch, R. B. (1966). The role of nasal secretion and serum antibody in the rhinovirus common cold. American Journal of Epidemiology 84, 352-363.

Clements, M. L., O'Donnel, S., Levine, M. M., Chanock, R. M. \& Murpiy, B. R. (1983). Dose response of $A / A l a s k a / 6 / 77$ (H3N2) cold-adapted reassortant vaccine virus in adult volunteers; role of local antibody in resistance to infection with vaccine virus. Infection and Immunity 40, 1044-1051.

Covch, R. B., Kasel, J. A., Six, H. R., Cate. T. R. \& Zahradnik, J. M. (1984). Immunological reactions and resistance to infection with influenza virus. In The Molecular Virology and Epidemiology of Influenza. (ed. C. H. Stuart-Harris and C. W. Potter), pp. 119-152. London: Academic Press.

Crifo, S., Vella, S., Filiaci, F., Resta, S. \& Rocchi, G. (1980). Secretory immune response after nasal vaccination with live attenuated influenza virus. Rhinology 18, 87-02.

Edsondson, W. P., Purcell, R. H., Gundelfiveer, B. F., Love, J. W. P., Ludwia, W. \& CHANock, R. M. (1966). Immunization by selective infection with type 4 adenovirus grown in human diploid tissue culture. Journal of the American Medical Association 195, 453-459.

Fleet, IV. F., Covch, R. B., CATE, T. R. \& Knight, V. (1965). Homologous and heterologous resistance to rhinovirus common cold. American Journal of Epidemiology 82, 185-196.

Frenstone, D. S., Hamitow-Smith, S., Schild, G. C., Buckland, R., Cuinn, S. \& Tyrrelu, D. A. J. (1072). Antibody responses and resistance to challenge in volunteers vaccinated with live attenuated detergent split and oil adjurant A2/Hong Kong/68 (H3N2) influenza vaccines. Journal of Hygiene 70, 531-543.

HAMrk, D. \& Bkm, Il. (1972). Virological studies of acute respiratory disease in young adults. $\checkmark$. Coronavirus $229 \mathrm{E}$ infections during six years of surveillance. American Journal of Epidemiology 96, 04-106. 
Hendefy, J. O., Gwalteney, J. M. Jn \& Jordan, W. S. (1969). Rhinovirus infections in an industrial population. IV. Infections within families of employees during two fall peaks of respiratory illness. American Journal of Epidemiology 89, 184-106.

Hermans, J. F. (1075). The secretory immune system. A critical appraisal. In The Immune System and Infectious Diseases, 4th International Convocntion of Immunology, Buffalo, N.Y. 1974, pp. 376-385. Basel: Karger.

Higoins, P. G., Phillpotts, R. J., Scott, G. M., Wallace, J., Bernhardt, L. L. \& Trkrhll, D. A. J. (1083). Intranasal interferon as protection against experimental respiratory coronavirus infection in volunteers. Antimicrobial Agents and Chemotherapy 24, 713-715.

Holmes, M. J. (1073). Respiratory virus disease in the Antarctic: Immunological studies. In Polar Human Biology (ed. O. G. Edholm and E. K. E. Gunderson), pp. 125-134. London: Heinemann Medical Books.

Holmes, M. J., Reed, S. E., Stott, E. J. \& Tyrrell, D. A. J. (1976). Studies of experimental rhinovirus type 2 infections in polar isolation and in England. Journal of Hygiene 76, 379-393.

Jemmotт, J. B., Borysenko, J. Z., Borysenko, M., McClella do, D. C., Chapman, R., MIeyer, D. \& Benson, H. (1083). Academic stress, power motivation and decrease in secretion rate of salivary secretory immunoglobulin A. Lancet i, 1400-1402.

KraAiJeveld, C. A., Madae, M. H. \& MacNaughton, M. R. (1980). Enzyme-linked immunosorbent assay for coronaviruses HCV 229 E and MHV 3. Journal of General Virology 49, 83-89.

LiDWELL, O. M. \& Sommerville, T. (1951). Observations on the incidence and distribution of the common cold in a rural community during 1948 and 1949. Journal of Hygiene 49, 365-381.

LidWELL, O. M. \& Williams, R. E. O. (1961 a). The epidemiology of the common cold. I. Journal of Hygiene 59, 309-319.

LIDWELL, O. M. \& WILLIaMs, R. E. O. ((1061b). The epidemiology of the common cold. II. Cross-infection and immunity. Journal of Hygiene 59, 321-334.

Lowry, O. H., Rosenbrovah, N. J., Farr, A. L. \& Randall, R. J. (1951). Protein mensurement with the folin phenol reagent. Journal of Biological Chemistry 193, 265-275.

MatThews, T. H. J., Nalr, C. D. G., Lawrence, M. K. \& Tyrrell, D. A. J. (1976). Antiviral activity in milk of possible clinical importance. Lancet ii, 1387-1389.

McCormick, D. P., Wenzel, R. P., Davies, J. A. \&Beam, W. E. (1972). Nasal secretion protein responses in patients with wild-type adenovirus disease. Infection and Immunity 6, 282-288.

Milts, J., van Kirk, J. E., Wright, P. F. \& Chanock, R. M. (1971). Experimental respiratory syncytial virus infection of adults. Journal of Immunology 107, 123-130.

Monto, A. S. (1974). Coronaviruses. Yale Journal of Biology and Medicine 47, 234-251.

Murpiy, B. R., Chaliuub, E. G., Nusinoff, S. R., Kasel, J. \& Chanock, R. M. (1973). Temperature-sensitive mutants of influenza virus. II. Further characterization of the ts-1(E) influenza $A$ recombinant (H3N2) virus in man. Journal of Infectious Diseases 128, 479-487.

Oara, P. L., Coppola, P. R., MacGillivray, M. H. \& Dzierba, J. L. (1974). Mechanism of mucosal immunity to viral infections in $\gamma \mathrm{A}$ immunoglobulin-deficiency syndromes. Proceedings of the Society for Experimental Biology and Medicine 145, 811-816.

Perkins, J. C., Tucker, D. N., Knopf, H. I.. S., Wenzel, R. P., Kapikian, A. Z. \& Chanock, R. M. (1069). Comparison of protective effect of neutralizing antibody in serum and nasal secretions in experimental rhinovirus type 13 illness. American Journal of Epidemiology 90, $510-526$.

PhillpotTs, R. J. (1083). Clones of JIRC.C cells may be superior to the parent line for the culture of $220 \mathrm{E}$-like strains of human respirntory coronavirus. Journal of Virological Methods 6 , 267-260.

REED, S. E. (1984). The behaviour of recent isolates of human respiratory coronavirus in vitro and in volunteers: evidence of heterogeneity among $229 \mathrm{E}$-related strains. Journal of Medical Virology 13, 170-103.

REed, S. E. \& HALL, T. S. (1973). Hemagglutination-inhibition test in rhinovirus infections of volunteers. Infection and Immunily 8, 1-3.

Ruodes, K., ScotT, A., Markilan, R. L. \& Monk-Jones, M. E. (1069). Immunological sex differences. $A$ study of patients with rheumatoid arthritis, their relatives and controls. Annals of the Rheumatic Disenses 28, 104-119.

Rossen, R. D., Butren, W. T., IVatddian, R. H., Alford, R. H., Hornick, R. B., Toco, Y. \& KASEL, J. A. (1970). The proteins in nasal secretion. II. A longitudinal study of IgA and neutralizing antibody levels in nasal washings from men infected with influenza virus. Journal of the American Medical Association 211, 1157-1161. 
Rossen, R. D., Schade, A. L., Butler, W. T. \& Kasel, J. A. (1966). The proteins in nasal secretion: a longitudinal study of the $\gamma$ A-globulin, $\gamma$ G-globulin, albumin, siderophilin, and total protein concentrations in nasal washings from adult male volunteers. Journal of Clinical Investigation 45, 768-776.

SA viluHT, E. (1973). IgA deficiency in children. Immunoglobulin-containing cells in intestinal mucosa, immunoglobulins in secretions and serum IgA levels. Clinical and Experimental Immunology 13, 395-406.

Sifofl, S. (1956). Non-parametric Statistics Table 87. New York: McGraw-Hill.

Siiti, C. B., Purceld, R. H., Bellanti, J. A. \& Chanock, R. M. (1966). Protective effect of antibody to parainfluenza type 1 virus. New England Journal of Medicine 275, 1145-1152.

South, M. A., Cooper, M. D., Wolliein, F. A. \& Good, R. A. (1968). The IgA system. II. The clinical significance of IgA deficiency: studies in patients with agammaglobulinemia and ataxia-telangiectasia. American Journal of Medicine 4, 168-178.

Stuart-Harris, C. H. \& Francis, T., JR (1938). Studies on the nasal histology of epidemic virus infection in the ferret. II. The resistance of regenerating respiratory epithelium to reinfection and to physico-chemical injury. Journal of Experimental Medicine 68, 803-812.

Tomasi, T. B. \& Decoteau, E. (1970). Mucosal antibodies in respiratory and gastro-intestinal disense. Advances in Internal Medicine 16, 401-425.

Tomasi, T. B., Tan, E. MI., Solomon, A. \& Prendergast, R. A. (1965). Characteristics of an immune system common to certain external secretions. Journal of Experimental Medicine 121, 101-125.

Totman, R., Kiff, J., Reed, S. E. \& Craia, J. W. (1080). Predicting experimental colds in volunteers from different measures of recent life stress. Journal of Psychosomatic Research 24, 155-163.

Totman, R., Reed, S. E. \& Craig, J. W. (1977). Cognitive dissonance, stress and virus-induced common colds. Journal of Psychosomatic Research 21, 55-63.

Tremonti, L. P., Lin, J. L. \& Jackson, G. G. (1968). Neutralizing activity in nasal secretions and serum in resistance of volunteers to parainfluenza virus type 2. Journal of Immunology $101,572-577$.

Tyrrell, D. A.J. \& Reed, S. E. (1973). Some possible practical implications of interferon and interference. In 'Non-specific' Factors Influencing Host Resistance (ed. W. Braun and J. Ungar), pp. 438-442. Basel: Karger.

Waldman, R. H. \& Hensey, C. S. (1971). Cell-mediated immunity and antibody responses in the respiratory tract after local and systemic immunization. Journal of Experimental Medicine $134,482-404$.

YodFAT, Y. \& Silvian, I. (1977). A prospective study of acute respiratory tract infections among children in a kibbutz: the role of secretory IgA and serum immunoglobulins. Journal of Infectious Diseases 136, 26-30. 